\title{
EXUAL MATURITY OF THE SMALL SHRIMP POTIMIRIM brasiliana Villalobos, 1959 (Crustacea, Atyidae), FROM THE SOUTHEASTERN COAST OF BRAZIL
}

\author{
Marina Machado da Costa \\ Patrícia Hoffmann \\ Geslaine Rafaela Lemos Gonçalves
}

Maria lucia Negreiros-Fransozo

University of the São Paulo State, UNESP, Institute of Biosciences, Department of Zoology, Rua Prof. Dr. Antônio Celso Wagner Zanin, 250, Distrito de Rubião Junior, 18618-

689, Botucatu, São Paulo, Brazil, dorettomarina@outlook.com

\begin{abstract}
The shrimp Potimirim brasiliana plays an important role in streams along the Brazilian coast as it feeds on the organic debris from the surrounding ecosystem. We determined the morphological sexual maturity of $P$. brasiliana by means of relative growth. Monthly throughout a year, we used sieves ( $2 \mathrm{~mm}$ mesh diameter) to collect the specimens in a coastal stream. A total of 3,521 specimens had their carapace length (CL) measured, as well as their second pleura length (PL) and the length $(A M L)$ and width $(A M W)$ of the appendix masculina. The studied relationships were the following: CL vs. PL; CL vs. AML and CL vs. AMW, with the data adjusted to a logistic equation. All the relationships tested among the demographic groups differed statistically. The $\mathrm{CL}_{50}$ of females measured $3.45 \mathrm{~mm}$, while the $\mathrm{CL}_{50}$ of males measured $2.75 \mathrm{~mm}$. Two adult morphological groups were set apart for each sex. The CL vs. AMW relationship is the best at demonstrating the separation of the morphological groups for males. This fact is an intriguint issue as it suggests the presence of morphotypes in males, probably, playing different roles in the reproductive process.
\end{abstract}

Keywords: Caridea, morphology, reproduction, Ubatuba.

\section{Maturidade sexual do camarão miúdo, Potimirim brasiliana Villalobos, 1959 (Crustacea, Atyidae), Proveniente do litoral sudeste brasileiro}

Resumo: O camarão miúdo, Potimirim brasiliana, possui uma importante função nos riachos litorâneos do litoral brasileiro, uma vez que ele se alimenta de detritos orgânicos oriundos dos ecossistemas vizinhos. A maturidade sexual morfológica de $P$. brasiliana foi estimada por meio do crescimento relativo. Os espécimes foram capturados num riacho litorâneo, mensalmente, por um ano, utilizando-se peneiras ( $2 \mathrm{~mm}$ de diâmetro). Um total de 3521 espécimes foi mensurado quanto ao comprimento da carapaça $(\mathrm{CL})$; comprimento da segunda pleura (PL); comprimento (AML) e largura (AMW) do appendix masculina. As relações estudadas foram as seguintes: CL vs. PL; CL vs. AML e CL vs. AMW. Os dados foram ajustados a uma equação logística. Todas as relações testadas entre os grupos demográficos diferiram estatisticamente. $O \mathrm{CL}_{50}$ determinado para as fêmeas foi de $3.45 \mathrm{~mm}$. Esta espécie apresentou dois grupos morfológicos adultos em cada sexo. A relação CL vs. AMW representou melhor a separação entre os grupos morfológicos de machos; cujo valor registrado para o $\mathrm{CL}_{50}$ de machos foi $2.75 \mathrm{~mm}$. Tal fato é intrigante, uma vez que sugere a formação de morfotipos em machos, provavelmente, apresentando funções distintas no processo reprodutivo.

Palavras-chave: Caridea, morfologia, reprodução, Ubatuba. 


\section{INTRODUCTION}

Studies on the relative growth of animals have begun mid last century, mainly on crustaceans, by Teissier (1935, 1960), Huxley \& Teissier (1936), Newcombe (1948) and Hartnoll $(1978,1982)$. These authors showed that the relationship between the growth of one body part or organ in relation to the whole body can be described by the power equation $\left(Y=a X^{b}\right)$, where $Y$ is the variable dimension, $X$ the reference dimension, while $a$ and $b$ are constants (Huxley \& Teissier, 1936).

The growth of crustaceans is well known due to its rigid tegument that allows for accurate measurements and also because the molting process (exoskeleton shedding) delimits their well-defined life cycle stages (Hartnoll, 1978 and Petriella \& Boschi, 1997). Generally, there are fewer studies on caridean shrimps than on brachyurans and the majority of them addresses the relative growth of species with economic interest, particularly, many studies on the genus Macrobrachium Bate, 1868 such as Valenti et al. (1989), Moraes-Riodades \& Valenti (2002, 2004), Mossolin \& Bueno (2003), Mantelatto \& Barbosa (2005), Konan et al. (2010), Pantaleão et al. (2012), Bueno et al. (2019) and Nogueira et al. (2019). In addition, there are a few studies focused on other caridean genera, such as: Anger \& Moreira (1998), Martínez-Mayén et al. (2000), LozanoAlvarez et al. (2007), Paschoal et al. (2013a), Herrera et al. (2018) and Pescinelli et al. (2018).

The changes in the proportions of body size and its parts are noted on the relative growth of the secondary sexual characters, mainly those associated with the reproduction of decapods (Hartnoll, 1974; Gonçalves et al., 2017). For instance, thalassinids, anomurans and brachyurans show morphological changes in the male chelipeds and the female abdomen, which commonly characterize the transition from morphologically immature to the mature stage (Flores \& Negreiros-Fransozo, 1999; Bertini \& Fransozo, 1999; Negreiros-Fransozo \& Fransozo, 2003; Hirose \& Negreiros-Fransozo, 2007 and Bertini et al., 2007).

In carideans, both sexes have morphological variations related to reproduction. According to Bauer (2004) in caridean males, "the endopod of the first pleopod pair is usually different from other pleopods, indicating some sexual function" (Bauer, 2004); while "females show distinct variations in the structure of the pleopods when in breeding condition, which are related to incubation of embryos, i.e., "brood pouch".

One can assess the sexual maturity of decapod crustaceans grounded on three lines: morphological maturity, which is usually based on changes in the relative growth of secondary sexual characters; physiological or histological maturity, evidenced by the presence of mature oocytes, spermatozoon or spermatophores; and functional maturity, the capacity to copulate and carry embryos (López-Greco et al., 1999; Viau et al., 2006 and Gonçalves et al., 2016).

According to De Grave \& Fransen (2011), the infraorder Caridea, the second most speciesrich group within Decapoda, corresponds to half as many species as in Brachyura. The same authors also mentioned that this infraorder is dominated by Palaemonidae (981 species), followed by Alpheidae (663), Atyidae (469), Hippolytidae (338) and Crangonidae (219), in addition to 12 monogeneric families, for instance, Physetocarididae.

The Atyidae family comprises freshwater shrimps (De Grave et al., 2008, 2009; De Grave \& Fransen, 2011) and shows a remarkable diversity. They are represented in the Neotropical region by 19 species (De Grave et al., 2008).

The genus Potimirim Holthuis, 1954, whose meaning in a Brazilian native language (Tupi-Guarani) is "small shrimp", occurs in coastal rivers and streams from Mexico, Central America and South America (Torati \& Mantelatto, 2012). This genus comprises five valid species, among them Potimirim brasiliana Villalobos, 1959 and Potimirim potimirim (Müller, 1881). These species are native to rivers along the Brazilian coast, i.e., Bahia, Rio de Janeiro, São Paulo, Paraná and Santa Catarina as mentioned by Almeida et al. (2008), Hoffmann \& Negreiros-Fransozo (2010) and Torati \& Mantelatto (2012). Recently, Moraes et al. (2017) recorded $P$. potimirim in Rio Grande do Norte, Brazil, extending its geographic distribution.

The shrimp $P$. brasiliana lives amongst macrophytes, partially submerged along the river margins, and on the vegetal material deposited on the bottom of clear-water rivers flowing towards the sea (Barros \& Fontoura, 1996b). Therefore, $P$. brasiliana is an important component of the freshwater environment it inhabits, due to its fundamental role in the transportation and retention of debris, and in the recycling of nutrients (Covich et al., 1999; Crowl et al., 2001). It also contributes to the renewal and resuspension of sediments (Moulton et al., 2004) and it cleans the hard substratum exerting a negative influence on the periphyton (Souza \& Moulton, 2005). We believe that such activities are related to the feeding habits and the existence of certain morphological structures, i.e., specialized setae for capturing organic debris from the water and substratum. 
A few studies on the genus Potimirim are available in the literature such as: population biology by Lima et al. (2006), molecular phylogeny by Torati \& Mantelatto (2012), evaluation of the role of some macrophytes in populations of carideans by Paschoal et al. (2013b), reproductive and population aspects of $P$. brasiliana by Rocha et al. (2013), and the sexual system by Grilli et al. (2014).

Nevertheless, additional data on the general biology of $P$. brasiliana is scarcely found. The reproductive biology and growth of $P$. brasiliana (published as $P$. glabra) were described by Barros \& Fontoura (1996a) and Hoffmann \& Negreiros-Fransozo (2010) for populations of Santa Catarina and São Paulo, respectively.

Under these circumstances, we analyzed a population of $P$. brasiliana from a coastal stream in Ubatuba, São Paulo, southeast Brazil, regarding its morphological sexual maturity, based on its relative growth. The results obtained here will allow a better understanding of specie's biology in order to set better guidelines to protect it against human interference, such as sewage or industrial discharge and the construction of piers in areas of procreation and development for many species.

\section{MATERIAL AND METHODS}

The shrimps were sampled monthly, from March 2005 to February 2006, in a small river in the Camburi district (23022'072" S; 44046'702" W), a touristic and residential area of Ubatuba, São Paulo, Brazil. The Camburi River has a clear and turbulent water due to a narrow riverbed, large algae-covered rocks, and a very irregular margin (Hoffmann, 2007). The marginal vegetation is very rich, comprised of bushes and trees that offer shade in a landscape with little human influence along the river within the Atlantic forest (Hoffmann, 2007).

We captured the shrimps using a conical sieve ( $2 \mathrm{~mm}$ mesh) to hand-sieve under water, very near the rocks. We placed the specimens in plastic bags with water from the sampling site, labelled and kept them in thermal boxes. After that, we identified the shrimps by the diagnostic features indicated by Villalobos (1959) and Grilli et al. (2014). In the laboratory, we separated the specimens into demographic groups (juveniles, males, females and ovigerous females) and conserved them in ethanol $(70 \%)$.

Individuals were sexed according to the presence of an appendix masculina on the second pair of pleopods, which is a very conspicuous morphological structure that characterizes males in species of the genus Potimirim (Villalobos, 1959; Hoffmann, 2007 and Hoffmann \& Negreiros-Fransozo, 2010).
In the case of shrimps with lost or broken pleopods, sexing was based on the presence (males) or absence (females) of a pair of spines close to the proximal articulation of the carpus on the third pair of pereiopods, which in taxonomical descriptions are considered to be the "male sexual organs" (Villalobos, 1959; Hoffmann \& Negreiros-Fransozo, 2010).

The measurements used for the morphometric analysis in this study were adopted from Hoffmann \& Negreiros-Fransozo (2010). We measured the carapace length $(\mathrm{CL})$ of both sexes. For females, we measured the pleura length of the second abdominal somite (PL) that is associated with reproduction as it protects the embryos during incubation (Bauer, 2004). For males, we measured the appendix masculina of the second pair of pleopods in two portions: length (AML) and width (AMW). Measurements were made using a microscope stereoscope (SV6, Zeiss) equipped with an image system (Axiovision, Zeiss: $0.01 \mathrm{~mm}$ ).

In the relative growth analysis, we adopted as dependent variables the dimensions $\mathrm{PL}, \mathrm{AML}$ and $\mathrm{AMW}$ ( $\mathrm{Y}$ axis), and as independent variable (X-axis), the dimension $\mathrm{CL}$.

\section{Statistical Analysis}

We used the allometric technique described by Huxley (1950) to determine the morphologic sexual maturity of $P$. brasiliana, based on the measurements of their body parts. For the allometry analysis, we selected a higher number of individuals than those mentioned in Hoffmann (2007) due to the high number of shrimps caught. Separate equations were calculated for each sex. This technique allows us to observe variation in the growth pattern of certain body parts through a slope change on the straight line.

The data were log-transformed and fitted to a linear model. The degree of allometry (positive $>1$, negative $<1$ or isometric $=1$ ) was checked using a Student's T-test, with a significance level of $5 \%(\alpha=0.05)$ (Sampedro et al., 1999).

The process to isolate data in groups of juveniles and adults did not vary between sexes. Before the classification into juveniles or adults, we isolated the set of data in two groups using the "K-means clustering" method (Legendre \& Legendre, 2012) in the bivariate set of data that consists of a standardized residual of the variables used for each sex. Subsequentially, we proceeded to the discriminant analysis for reallocation of any incorrectly classified datum.

The specimens belonging to the Morphotype-I were designated as adults I, and Morphotype-II as adults II. We used the same process for each studied relationship. The 
separation of data into groups of juveniles and adults (I and II) adopted the analytical procedures described in detail by Bueno \& Shimizu (2009) and Hirose et al. (2012).

Linear regression was applied for each dependent variable in each group of data, previously distinguished in the $\mathrm{K}$-means clustering analysis. When absolute value data corresponding to the residual pattern were higher than 2.57 ( $p<0.01$ ) (Sokal \& Rohlf, 1995), they were considered not belonging to the distribution (= outlier), a measure also taken by Bueno \& Shimizu (2009).

When we found a significant difference in the regression parameters (between juveniles and adults), we determined the $\mathrm{CL}$ at the onset of morphologic sexual maturity for both sexes and for each size. Then, in order to verify the precision for each group, the slopes (b) and the intercepts (a) of the equations of every demographic group were tested using a covariance analysis (ANCOVA), at the significance level of $5 \%(=0.05)$ (Zar, 1999). Sta- tistical calculations were performed with the software Past (version 1.62) (Hammer et al., 2001) and Statistica (version 8.0).

\section{RESULTS}

\section{THE SAMPLED POPULATION}

We measured 618 juveniles (males and females), 1482 adult females and 1421 adult males (Tab. 1). Among the specimens of adult females, 482 of them were carrying embryos in the setae of their pleopods, and we named them as ovigerous females. Shrimps were not checked with respect spermatozoon presence by means smear for sexual classification.

\section{Size OF THE SPECIMENS}

We considered the size of the shrimps as the carapace length. The males varied in size from 1.8 to $4.6 \mathrm{~mm} \mathrm{CL}$, while the females varied from 1.5 to $5.5 \mathrm{~mm} \mathrm{CL}$ and the ovigerous females from 3.2 to $5.5 \mathrm{~mm} \mathrm{CL}$ (Tab. 2).

Tab. 1. Potimirim brasiliana Villalobos, 1959. Results of the relative growth based on the allometric technique of a population sampled in Ubatuba, São Paulo, Brazil.

\begin{tabular}{|c|c|c|c|c|c|c|c|c|}
\hline \multirow{2}{*}{ Relationships } & \multirow{2}{*}{ Sex } & \multirow{2}{*}{$\begin{array}{c}\text { Demographic } \\
\text { category }\end{array}$} & \multirow{2}{*}{$\mathbf{N}$} & \multicolumn{3}{|c|}{$\log Y=a+b \log X$} & \multirow{2}{*}{$(b \stackrel{t}{=} 1)$} & \multirow{2}{*}{ Allometry } \\
\hline & & & & $\mathbf{a}$ & $\boldsymbol{b}$ & $\mathbf{r}^{2}$ & & \\
\hline \multirow{3}{*}{$\mathrm{CL}$ vs. PL } & & J & 539 & -0.24 & 1.09 & 0.86 & $1.648^{*}$ & + \\
\hline & 우 & F I & 1000 & -0.29 & 1.25 & 0.72 & $1.648^{*}$ & + \\
\hline & & F II & 482 & -0.13 & 1.08 & 0.87 & $1.648^{*}$ & + \\
\hline \multirow{3}{*}{ CL vs. AML } & & J & 79 & -0.38 & 1.29 & 0.18 & $0.932 *$ & + \\
\hline & $\hat{o}$ & M I & 405 & -0.12 & 0.99 & 0.59 & $1.648^{\mathrm{ns}}$ & 0 \\
\hline & & M II & 706 & 0.21 & 1.31 & 0.39 & $1.647 *$ & + \\
\hline \multirow{3}{*}{ CL vs. AMW } & & J & 77 & -1.05 & 1.69 & 0.13 & $1.665^{*}$ & + \\
\hline & $\hat{\jmath}$ & M I & 715 & -0.41 & 1.31 & 0.63 & $1.646 *$ & + \\
\hline & & M II & 706 & 0.17 & 1.13 & 0.41 & $1.648 *$ & + \\
\hline
\end{tabular}


Tab. 2. Potimirim brasiliana Villalobos, 1959. Comparison of regressions (J, M I and M II) for each sex using ANCOVA.

\begin{tabular}{|c|c|c|c|c|c|c|c|c|c|}
\hline \multirow{2}{*}{$\begin{array}{c}\text { Smallest } \\
\text { shrimp } \\
(\mathbf{m m})\end{array}$} & \multirow{2}{*}{$\begin{array}{c}\text { Largest } \\
\text { shrimp } \\
(\mathbf{m m})\end{array}$} & \multirow{2}{*}{ Sex } & \multirow{2}{*}{$\begin{array}{l}\text { CL50 } \\
(\mathbf{m m})\end{array}$} & \multirow{2}{*}{ Rel. } & \multicolumn{5}{|c|}{ ANCOVA $(\alpha=5 \%)$} \\
\hline & & & & & $\begin{array}{c}\text { Demographic } \\
\text { category }\end{array}$ & Factor & $\boldsymbol{F}$ & $\mathbf{P}$ & Sign \\
\hline \multirow{2}{*}{1.5} & \multirow{2}{*}{3.3} & \multirow{6}{*}{ 우 } & \multirow{6}{*}{3.45} & \multirow{6}{*}{$\mathrm{CL}$ vs. PL } & \multirow{2}{*}{ J vs. F I } & a & 54.85 & 0.00 & $*$ \\
\hline & & & & & & $b$ & 25.29 & 0.01 & * \\
\hline \multirow{2}{*}{$3.2 * *$} & \multirow{2}{*}{5.5} & & & & \multirow{4}{*}{ F I vs. F II } & a & 596.75 & 0.00 & $*$ \\
\hline & & & & & & $b$ & 596.75 & 0.00 & $*$ \\
\hline \multirow{2}{*}{4.3} & \multirow{2}{*}{5.5} & & & & & a & 322.85 & 0.00 & $*$ \\
\hline & & & & & & $b$ & 322.85 & 0.00 & $*$ \\
\hline \multirow{2}{*}{1.8} & \multirow{2}{*}{3.1} & \multirow{6}{*}{$\hat{\delta}$} & \multirow{6}{*}{2.75} & \multirow{6}{*}{ CL vs. AML } & \multirow{2}{*}{ J vs. M I } & a & 13.83 & 0.00 & $*$ \\
\hline & & & & & & $b$ & 2.38 & 0.12 & ns. \\
\hline \multirow{2}{*}{2.6} & \multirow{2}{*}{4.5} & & & & \multirow{4}{*}{ M I vs. M II } & $a$ & 10.27 & 0.00 & $*$ \\
\hline & & & & & & $b$ & 0.02 & 0.90 & ns. \\
\hline \multirow{2}{*}{2.9} & \multirow{2}{*}{4.6} & & & & & a & 35.30 & 0.00 & $*$ \\
\hline & & & & & & $b$ & 18.52 & 0.00 & $*$ \\
\hline \multirow{2}{*}{1.8} & \multirow{2}{*}{2.9} & \multirow{6}{*}{$\hat{\delta}$} & \multirow{6}{*}{2.75} & \multirow{6}{*}{ CLvs. AMW } & \multirow{2}{*}{ J vs. M I } & a & 25.41 & 0.00 & $*$ \\
\hline & & & & & & $b$ & 2.80 & 0.10 & ns. \\
\hline 26 & 46 & & & & 1 Kc M U & $a$ & 15.56 & 0.00 & $*$ \\
\hline 2.0 & 4.0 & & & & 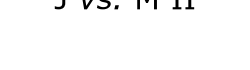 & $b$ & 4.09 & 0.04 & $*$ \\
\hline 2.7 & 4.2 & & & & M I vs. M II & $a$ & 32.35 & 0.00 & $*$ \\
\hline & & & & & & b & 7.18 & 0.07 & $*$ \\
\hline
\end{tabular}

$\mathrm{CL}_{50}=$ size in which $50 \%$ of shrimps are mature; $\mathrm{CL}=$ carapace length; $\mathrm{PL}=$ pleura length; $\mathrm{AML}=$ length of the appendix masculina; AMW = width of the appendix masculina; F I = female morphotype I; F II = female morphotype II; M I = male morphotype I; M II = male morphotype II; and $\mathrm{J}=$ juvenile; $\mathrm{a}=$ intercept; $\mathrm{b}=$ slope; $\mathrm{F}=$ ANCOVA result; $\mathrm{P}=$ probability; $\mathrm{ns} .=$ non-significant; $*$ = significant at $5 \%$; $* *$ smallest size of adult ovigerous female. Rel.: Relationships. Sign.: Significance.

\section{StATISTICAL REsUlts}

Supported by the allometric technique, the relative growth analyses revealed positive allometry in the majority of the studied relationships ( $\mathrm{CL}$ vs. PL; CL vs. $\mathrm{AML}$ and $\mathrm{CL}$ vs. AMW), except for the demographic category of males M I (CL vs. AML), which showed isometry (see Tab. 1). As we can observe in the regressions (Fig. 1, 2 and 3), the shrimp P. brasiliana had morphotypes in the adult stage for both sexes (Tab. 1). This means that the studied dimensions ( $P L, A M L$ and $A M W$ ) grow at a higher rate than the carapace size $(C L)$, with exception of the M I stage (males) in which the appendix masculina increases proportionally to the carapace length $(\mathrm{CL})$.

The comparison of equations among the demographic categories (juveniles, morphotype I and morphotype II) showed differences between males and females in all combinations (see Tab. 2). Thus, it is necessary to represent the relative growth graphically for each sex and maturity stage (Fig. 1, 2 and 3; Tab. 2 and 3).

The size at which $50 \%$ of males were morphologically mature $\left(\mathrm{CL}_{50}\right)$ was $2.75 \mathrm{~mm}$ $\mathrm{CL}$; while for females it was $3.45 \mathrm{~mm} \mathrm{CL}$. Thus, males mature at smaller sizes than females.

\section{Discussion}

MORPHOMETRY AND MORPHOLOGICAL SEXUAL
MATURITY
Caridean shrimps are a very diverse
group of decapods, inhabiting several aquatic 


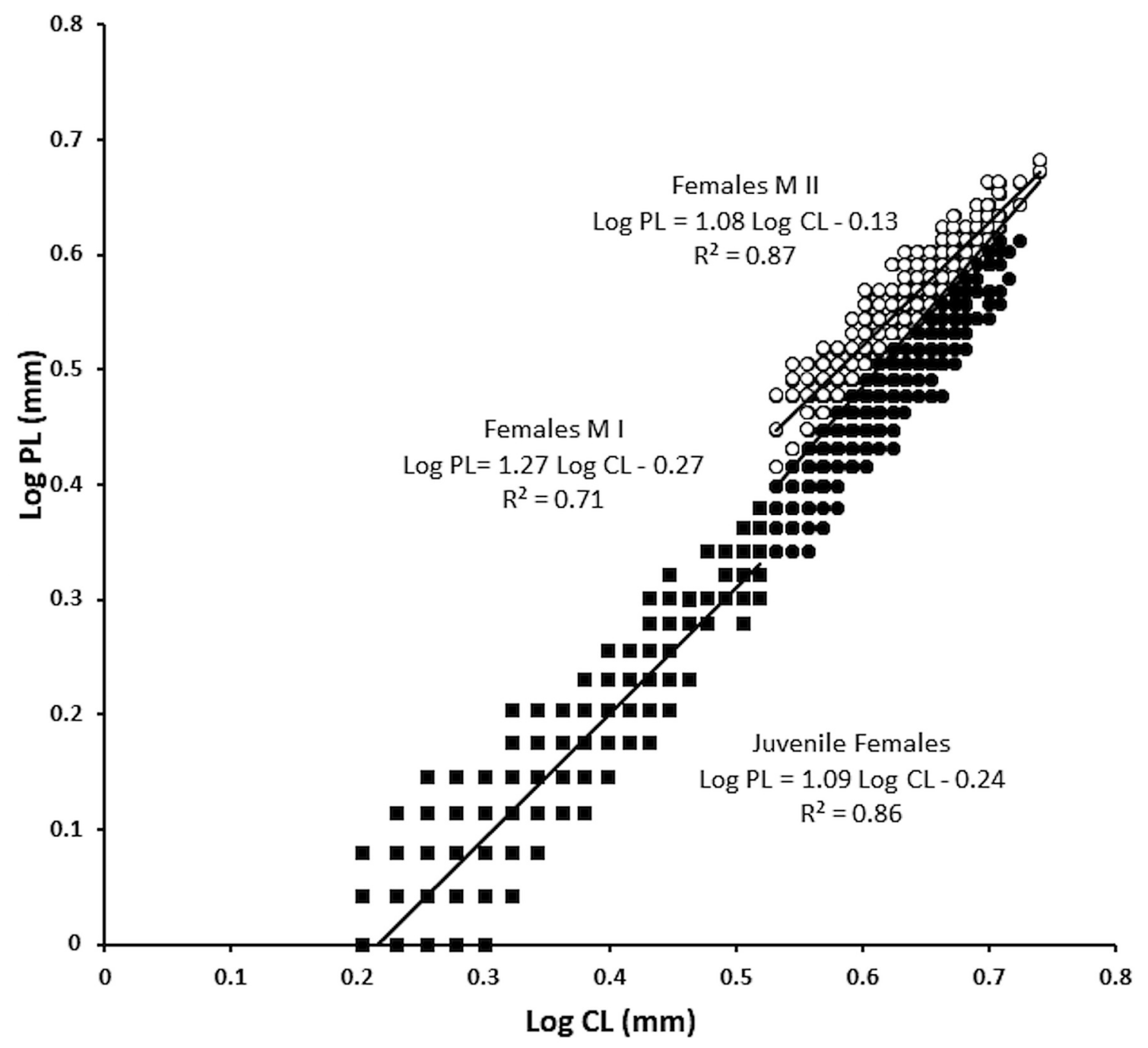

Fig. 1. Potimirim brasiliana Villalobos, 1959. Relationship between "carapace length vs. $2^{\text {nd }}$ Pleura length" for females (Juveniles and Adults - M I and M II) and the adjusted equations. (CL = carapace length; $\mathrm{PL}=2^{\text {nd }}$ Pleura length).

environments. However, so far, they have been scarcely studied with regards to their morphometry and sexual maturity associated with their relative growth. Species of the genus Macrobrachium (Palaemonidae family) are an exception, probably because some of them are of economic interest (Moraes-Riodades \& Valenti, 2002; Mossolin \& Bueno, 2003; Mantelatto \& Barbosa, 2005; Konan et al., 2010; Pantaleão et al., 2012; Bueno et al., 2019 and Nogueira et al., 2019). As stated by Hoffmann \& Negreiros-Fransozo (2010), the attainment of sexual maturity involves the development of secondary sexual characters, the maturation of the gonads and, in females, the capacity of generating offspring.

In most decapods studied, the relative growth of the chelipeds usually shows a positive allometry that represents the attainment of the sexual maturity in males (Flores \& NegreirosFransozo, 1999; Mantelatto \& Barbosa, 2005; Bertini et al., 2007; Hirose et al., 2012, 2017; Pantaleão et al., 2014, Nogueira et al., 2019). This was not observed in some of previously studied carideans, but both sexes probably have morphological variations linked to reproduction events, mainly mating behavior and incubation.

Berkeley (1930) and Descouterelle (1971) proposed that the appendix masculina has a key role in the spermatophore transfer. Mating experiments with other carideans confirm this view, for instance, Bauer (1976), Berg \& Sandifer (1984) and Nakashima (1995) on Heptacarpus sitchensis (Brandt, 1851), Palaemonetes pugio Holthuis, 1949 and Athanas kominatoensis (Kubo, 1942). In those studies, males lacking the endopod and the appendices 


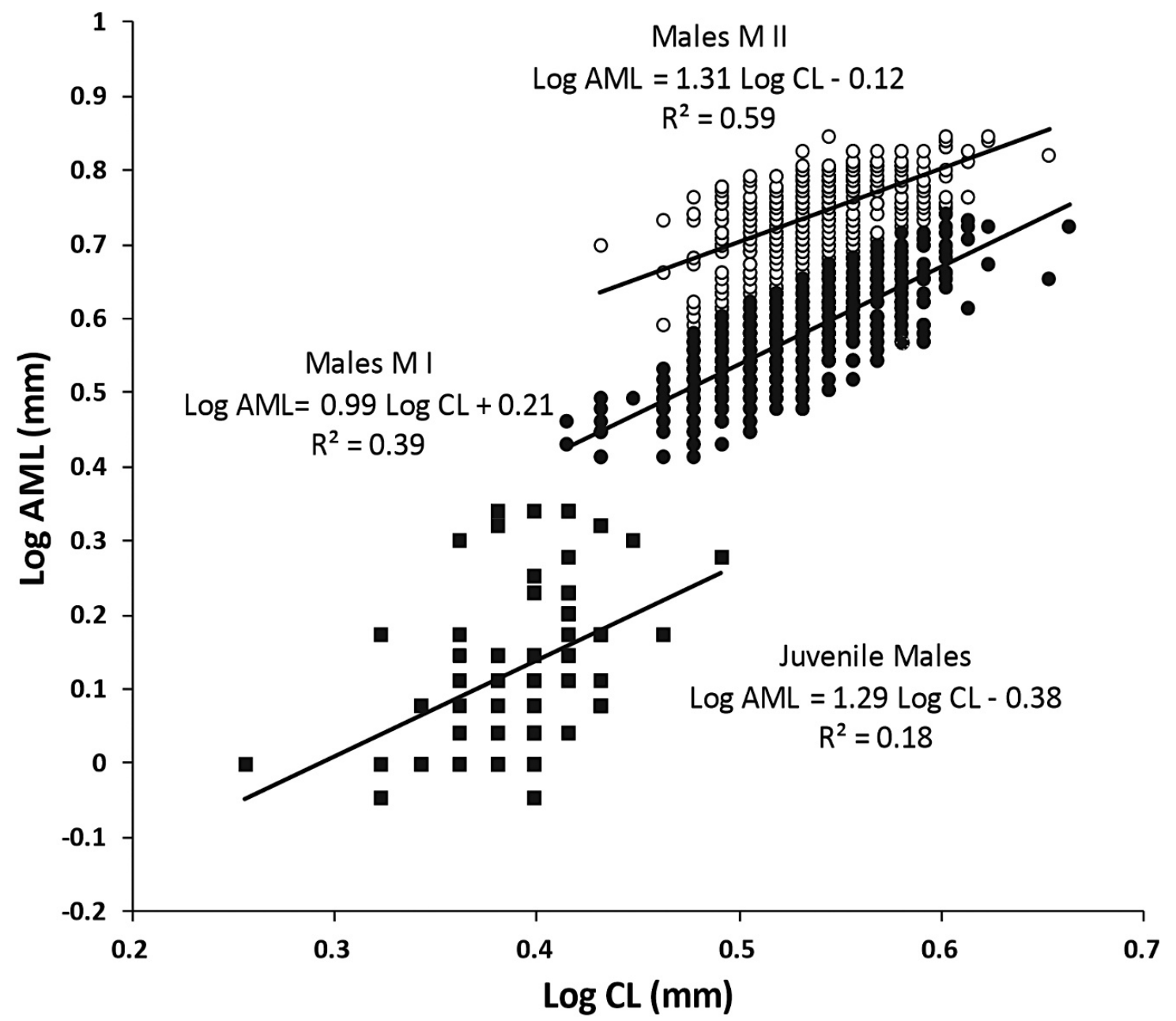

Fig. 2. Potimirim brasiliana Villalobos, 1959. Relationship between "carapace length vs. appendix masculina length" for males (Juveniles, Adults - M I and M II) and the adjusted equations. ( $\mathrm{CL}=$ carapace length; $A M L=$ appendix masculina length).

masculina of the second pleopods (they were removed) readily mated with females, but frequently failed to pass on spermatophores. According to Bauer (2004), caridean males have the endopod of the first pair of pleopods morphologically different from the other pleopods, indicating some kind of sexual function. Recently, Ahamed \& Ohtomi (2014) proposed that the appendix masculina in Plesionika izumiae Omori, 1971 has a secondary sexual character linked with morphological sexual maturity. Also, when studying six species of Alpheus Fabricius, 1798, Costa-Souza et al. (2019) found that the appendix masculina grows at a higher rate during the adult stage than the juvenile one.

Morphometric analysis of $P$. brasiliana confirmed the occurrences of different groups in both sexes after the sexual maturity $\left(\mathrm{CL}_{50}\right)$. The results obtained here indicate that the natural adult population of this species in Camburi
River is composed of two groups for each sex: females with different sizes of the second pleura and males with different sizes of the appendices masculina, a separation evidenced by the allometric constant from the morphometric relationships presented here. As shown by Moraes-Riodades \& Valenti (2004) and Pantaleão et al. (2014), a few carideans of the genus Macrobrachium have different morphotypes based on the growth of their chelipeds. Similarly, in the literature, it is suggested that these morphological differences are related to distinct behaviors between individuals, predominantly mating behavior. For instance, Barki et al. (1991) previously mentioned the importance of the morphological and allometric differences of the cheliped among morphotypes of Macrobrachium rosenbergii (De Man, 1879), regarding the dominance hierarchy. In $M$. rosenbergii, sexually mature males appear in three main morphotypes and several inter- 


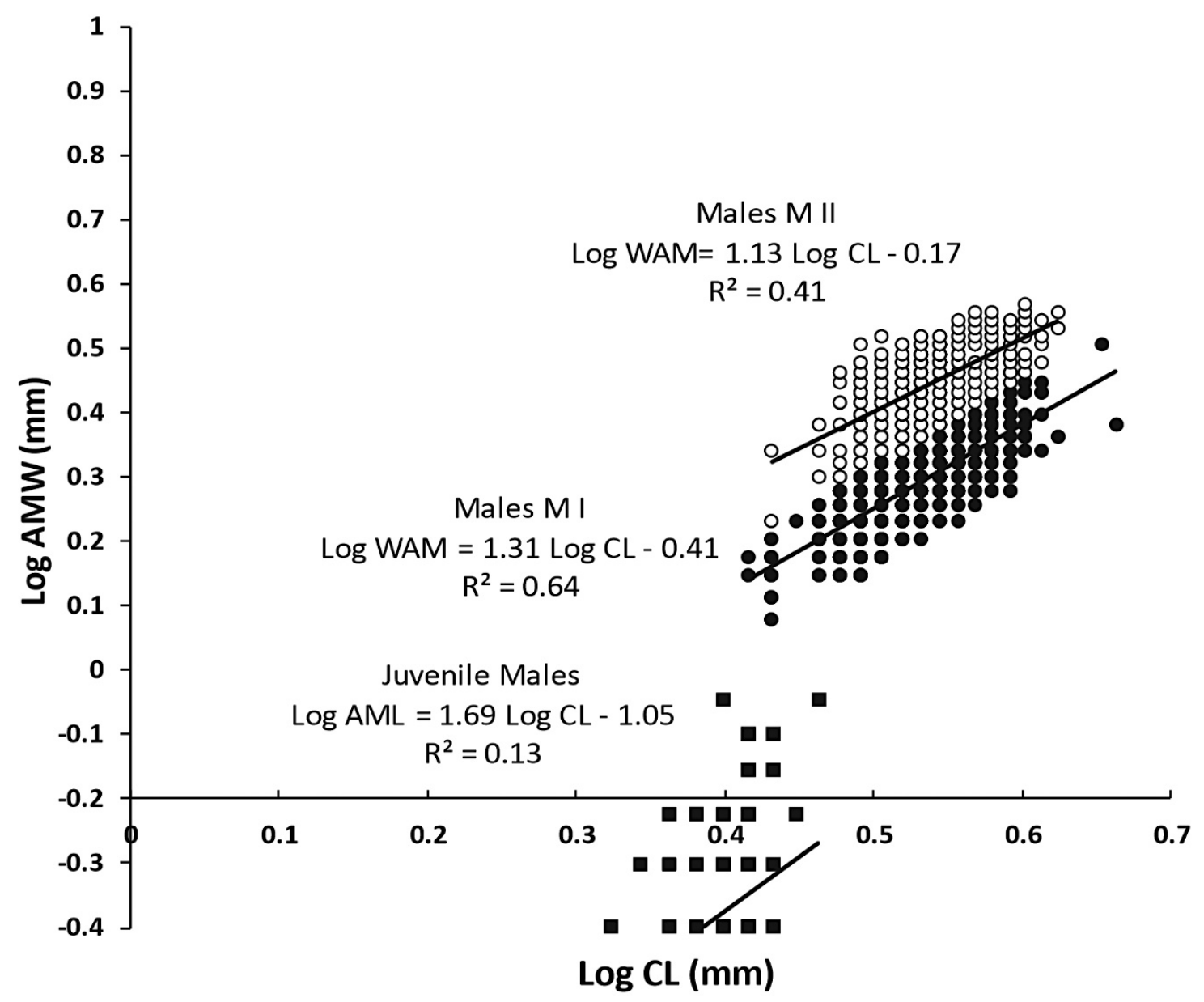

Fig. 3. Potimirim brasiliana Villalobos, 1959. Relationship between "carapace length vs. appendix masculina width" for males (Juveniles, Adults - M I and M II) and the adjusted equations. ( $C L=$ carapace length; $\mathrm{AMW}=$ appendix masculina width).

mediate forms with different morphology, anatomy, physiology and behavior (Karplus \& Sagi, 2010).

More recently, Augusto \& Valenti (2016) compared the metabolism, nitrogenous excretion, growth, substrate, ingestion rate, and fecal production of three male morphotypes $(\mathrm{CC}=$ cinnamon claw, $\mathrm{GC} 1=$ green claw 1 , and $\mathrm{GC2}=$ green claw 2) of Macrobrachium amazonicum (Heller, 1862). These authors concluded that the three morphotypes have different physiology regarding the parameters mentioned above, which might indicate their pattern of growth, activity, role within the population and the differences in their reproductive behavior.

Considering the results presented here for $P$. brasiliana, further studies on the hypotheses of distinct behaviors between morphotypes should help us better understand the actual role of the appendix masculina and the second pleura. Aside from Palaemonidae, other caridean shrimps such as Alpheidae,
Hippolytidae and Atyidae do not have similar mating behavior. In other words, adults of those three groups showed a less complex mating behavior and the males did not use the chelipeds to fight or compete with other males for a receptive female. Thus, the size of the cheliped in some species did not show differential growth between the juvenile and adult stages.

The functions of chelipeds or even of some pereiopods that can indicate growth in ontogenetic stages (morphotypes) of other decapods are not usually found in the present studied species of Caridea. However, the growth at different stages during the adult life of $P$. brasiliana could indicate a more efficient role in the morphotype II. We believe the appendix masculina is used in the moment of the sperm transfer, i.e., the male touches the pair of appendages next to the sternal area of the female to facilitate the deposition of the sperm mass near the gonopores. After that, the female 


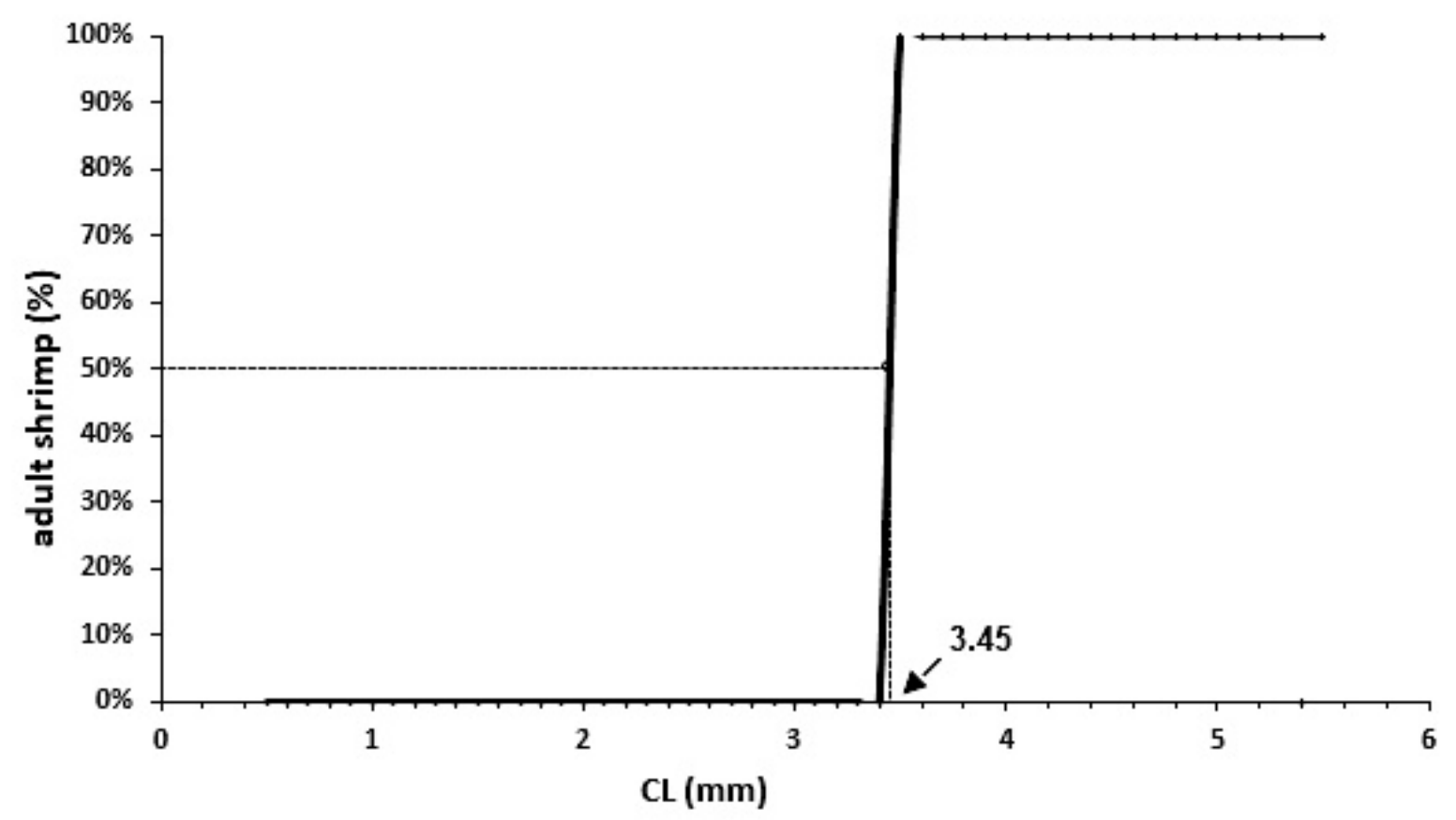

Fig. 4. Potimirim brasiliana Villalobos, 1959. Sexual maturity $\left(C_{50}\right)$ in females $(C L=$ carapace length).

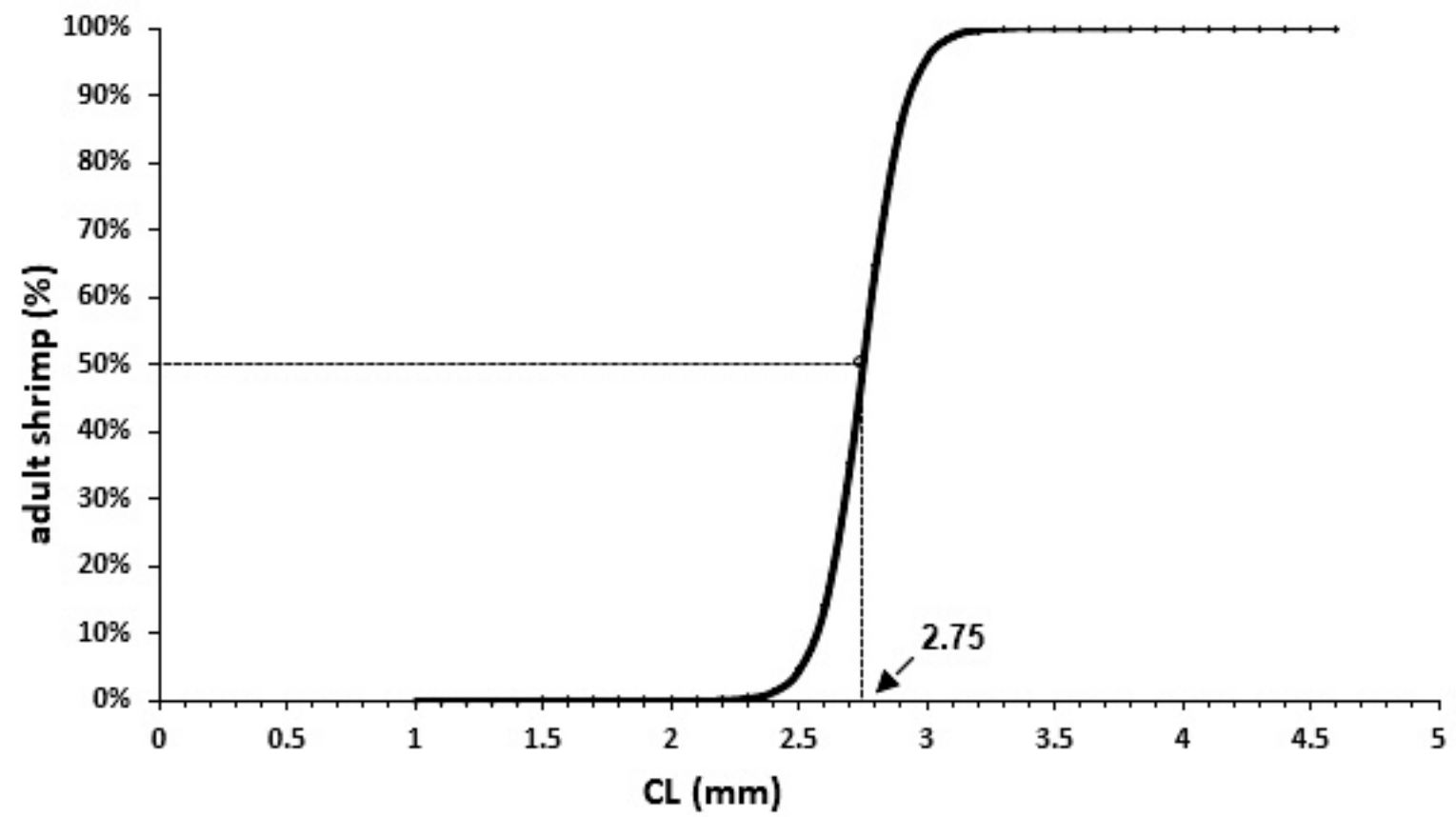

Fig. 5. Potimirim brasiliana Villalobos, 1959 . Sexual maturity sexual $\left(C_{50}\right)$ in males $(C L=$ carapace length).

spawns and the fertilization can occur in sequence. The type of mating behavior seen in shrimps living in huge groups in nature (like the species of the genus Potimirim) is named "Pure search" (Bauer, 2004). They mate among several individuals and the use of the appendix masculina could guarantee that the sperm mass does not drift in the water. The Atyidae, Atyaephyra desmaresti (Millet, 1931), showed positive allometry regarding the sexual endopod, in 
Tab. 3. Comparison between this study and previous ones on the relative growth and size at onset of sexual maturity for populations of Potimirim brasiliana from Brazilian coastal streams.

\begin{tabular}{|c|c|c|c|c|c|}
\hline $\begin{array}{l}\text { Location/ } \\
\text { Coordinates }\end{array}$ & $\begin{array}{l}\text { Sampling } \\
\text { date }\end{array}$ & $\begin{array}{l}\text { Number of } \\
\text { ovigerous } \\
\text { shrimps }\end{array}$ & $\begin{array}{c}\text { Ovigerous size } \\
\text { range (CL) } \\
\text { and/or Mean } \\
\text { value } \\
\end{array}$ & CL50 & References \\
\hline $\begin{array}{c}\text { Vigla's Beach, } \\
\text { Garopaba, Santa } \\
\text { Catarina } \\
28^{\circ} 01^{\prime} \text { S; } 48^{\circ} 35^{\prime} \mathrm{W}\end{array}$ & $\begin{array}{l}\text { From July, } \\
1993 \text { to } \\
\text { November, } \\
1994\end{array}$ & 529 & 4.9 to $7.4 \mathrm{~mm}$ & $\begin{array}{c}6.2 \text { to } 6.4 \\
\mathrm{~mm}^{*}\end{array}$ & $\begin{array}{c}\text { Barros \& } \\
\text { Fontoura (1996a, } \\
\text { 1996b) as } P . \\
\text { glabra }\end{array}$ \\
\hline $\begin{array}{l}\text { Juréla-Itatins } \\
\text { Ecological Station, } \\
\text { Peruíbe, São Paulo } \\
24^{\circ} 23^{\prime} \text { S; } 47^{\circ} 01^{\prime} \mathrm{W}\end{array}$ & $\begin{array}{l}\text { Spring of } \\
2000 \text { to } \\
\text { summer of } \\
2001\end{array}$ & 143 & 3.7 to $5.8 \mathrm{~mm}$ & $3.7 \mathrm{~mm} *$ & $\begin{array}{l}\text { Rocha et al. } \\
\text { (2013) }\end{array}$ \\
\hline $\begin{array}{c}\text { Ubatuba, São Paulo } \\
23^{\circ} 26^{\prime} \text { S }\end{array}$ & $\begin{array}{c}\text { January, } 1984 \\
\text { to February, } \\
1985\end{array}$ & 294 & $6.8 \pm 0.53 \mathrm{~mm}^{* *}$ & $5 \mathrm{~mm} * *$ & Molina (1987) \\
\hline $\begin{array}{c}\text { Camburl RIver, } \\
\text { Ubatuba, São Paulo } \\
23^{\circ} 22^{\prime} \text { 's; } 44^{\circ} 46^{\prime} \mathrm{W}\end{array}$ & $\begin{array}{l}\text { From March, } \\
2005 \text { to } \\
\text { February, } \\
2006,\end{array}$ & 481 & $\begin{array}{l}3.2 \text { to } 5.5 \mathrm{~mm} / \\
4.24 \pm 0.36 \mathrm{~mm}\end{array}$ & $3.2 \mathrm{~mm} *$ & $\begin{array}{c}\text { Hoffmann \& } \\
\text { Negreiros- } \\
\text { Fransozo }(2010)\end{array}$ \\
\hline $\begin{array}{c}\text { Indalá RIver } \\
\text { Ubatuba, São Paulo } \\
23^{\circ} 26^{\prime} \text { 's; } 44^{\circ} 46^{\prime} \mathrm{W}\end{array}$ & $\begin{array}{l}\text { From March, } \\
2005 \text { to } \\
\text { February, } \\
2006\end{array}$ & 391 & $\begin{array}{c}4.1 \text { to } 6.9 \mathrm{~mm} / \\
5.48 \pm 0.49 \mathrm{~mm}\end{array}$ & $4.1 \mathrm{~mm}^{*}$ & as $P$. glabra \\
\hline $\begin{array}{l}\text { Camburl River, } \\
\text { Ubatuba, São Paulo } \\
23^{\circ} 22^{\prime} \text { S; } 44^{\circ} 46^{\prime} \mathrm{W}\end{array}$ & $\begin{array}{l}\text { From March, } \\
2005 \text { to } \\
\text { February, } \\
2006\end{array}$ & $2021 * * *$ & 3.2 to $5.5 \mathrm{~mm}$ & $3.45 \mathrm{~mm}$ & Present study \\
\hline $\begin{array}{c}\text { Ariró River, Angra } \\
\text { dos Rels, Rlo de } \\
\text { Janeiro }\end{array}$ & $\mathrm{Nd}$, & $6 * * *$ & $8.1 \pm 0.51 \mathrm{~mm}$ & $6.93 \mathrm{~mm} *$ & VIllalobos (1959) \\
\hline $\begin{array}{c}\text { Rio Sahy, } \\
\text { Mangaratiba, Rlo } \\
\text { de Janeiro } \\
22^{\circ} 57^{\prime} \text { S; } 44^{\circ} 01^{\prime} \mathrm{W}\end{array}$ & $\begin{array}{l}\text { From } \\
\text { September, } \\
1997 \text { to } \\
\text { February, } \\
1999\end{array}$ & 204 & $\mathrm{Nd}$. & $\begin{array}{c}3.0 \text { to } 6.0 \\
\mathrm{~mm}\end{array}$ & $\begin{array}{c}\text { Lima \& Oshiro } \\
\text { (2002) and Lima } \\
\text { et al. (2006) as } \\
\text { P. glabra }\end{array}$ \\
\hline
\end{tabular}

its pleopod (Dhaouadi-Hassen \& Boumaiza, 2005).

In short, a new behavioral study using photo and video records associated with electronic scanning techniques are needed to test such hypothesis.

\section{ReLATIVE GROWTH}

The relative growth of the appendix masculina studied here for $P$. brasiliana (regressions $C L$ vs. $A M L$ and $C L$ vs. AMW) indicated positive allometry that conforms to the indication of some sexual function, mentioned by Bauer (2004). However, further studies on its mating behavior are needed to clarify that function. There might be an early (genetic) factor, operating long before sexual maturation that in combination with social factors contributes to the determination of morphotypes (Karplus \& Barki, 2019).

Analysis of the relative growth of the length of pleurae in females ( $C L$ vs. $P L$ ) revealed a conspicuous allometric rate that translates to an increase in pleura length from the juvenile to the adult stage. During the adult stage, the space below the pleura works as a brood pouch, when females start carrying embryos/eggs. Thus, as the space increases, more eggs are incubated, optimizing the reproductive process (Nazari et al., 2003; Bauer, 2004; Mortari et al., 2009; Paschoal et al., 2013a).

This study found no sign of slope changes when analyzing the size at sexual maturity of $P$. brasiliana (Tab. 3), along the latitudinal gradi- 
ent. Thus, in order to evaluate whether the relationship is latitudinal or local, we need further studies on the populations of $P$. brasilia$n a$ at different latitudes and different local environmental factors, mainly the quality of food resources.

\section{ACKNOWLedgements}

We are sincerely thankful to Dr. Roberto M. Shimizu and to Dr. Sérgio S. Bueno, both from Biosciences Institute, University of São Paulo (USP), who helped us with the allometry statistics. We are thankful to Eduardo Degani for English reviewing and anonimous'referees for their comments, which really improved the manuscript. The specimens obtained in this study were collected according to Brazilian laws concerning sampling of wild animals.

\section{REFERENCES}

Ahamed, F. \& J. Ohtomi. 2014. Relative growth and sexual maturity of the pandalid shrimp Plesionika izumiae (Decapoda, Caridea) in Kagoshima Bay, Southern Japan. Crustaceana. 87: 1567-1577.

Almeida, A. O., P. A. Coelho, J. R. Luz, J. R., J. T. A. Santos \& N. R. Ferraz. 2008. Decapod crustaceans in fresh waters of southeastern Bahia, Brazil. Rev. Biol. Trop. 56: $1225-1254$.

Anger, K. \& G. S. Moreira. 1998. Morphometric and reproductive traits of tropical and caridean shrimps. J. Crust. Biol. 18: 823-838.

Augusto, A. \& W. C. Valenti. 2016. Are there any physiological differences between the male morphotypes of the freshwater shrimp Macrobrachium amazonicum (Heller, 1862) (Caridea: Palaemonidae)? J. Crust. Biol. 36: 716-723.

Barki, A., I. Karplus \& M. Goren. 1991. Morphotype related dominance hierarchies in males of Macrobrachium rosenbergii (Crustacea, Palaemonidae). Behaviour. 117: 145-160.

Barros, M. P. \& N. F. Fontoura. 1996a. Biologia reprodutiva de Potimirim glabra (Kingsley, 1878) (Crustacea, Decapoda, Atyidae), na Praia da Vigia, Garopaba, Santa Catarina, Brasil. Nauplius. 4: 1-10.

Barros, M. P. \& N. F. Fontoura. 1996b. Crescimento de Potimirim glabra (Kingsley, 1878) (Crustacea, Decapoda, Atyidae) na
Praia da Vigia, Garopaba, Santa Catarina, Brasil. Nauplius. 4: 11-28.

Bauer, R. T. 1976. Mating behaviour and spermatophore transfer in the shrimp Heptacarpus pictus (Stimpson) (Decapoda: Caridea: Hippolytidae). J. Nat. His. 10: 315-440.

Bauer, R. T. 2004. Remarkable shrimps: adaptations and natural history of the carideans. 1st ed. (Norman: University of Oklahoma Press), $282 \mathrm{p}$.

Berg, A. B. \& P. A. Sandifer. 1984. Mating behavior of the grass shrimp Palaemonetes pugio Holthuis (Decapoda: Caridea). J. Crust. Biol. 4: 417-424.

Berkeley, A. A. 1930. The post-embryonic development of the common pandalids of British Columbia. Contr. Canad. Biol. Fish. 6: 79-163.

Bertini, G. \& A. Fransozo. 1999. Relative growth of Petrochirus diogenes (Linnaeus, 1758) (Crustacea, Anomura, Diogenidae) in the Ubatuba region, São Paulo, Brazil. Rev. Bras. Biol. 59: 617-625.

Bertini, G., A. A. Braga, A. Fransozo, M. 0. D. A. Corrêa \& F. A. M. Freire. 2007. Relative Growth and sexual maturity of the stone crab Menippe nodifrons Stimpson, 1859 (Brachyura, Xanthoidea) in Southeastern Brazil. Braz. Arch. Biol. \& Tech. 50: 259-267.

Bueno, S. L. S. \& R. M. Shimizu. 2009. Allometric growth, sexual maturity, and adult male chelae dimorphism in Aegla franca (Decapoda: Anomura: Aeglidae). J. Crust. Biol. 29: 317-328.

Bueno, A. P., C. R. Bonatto \& A. C. Almeida. 2019. Influence of environmental variables on seasonal abundance and relative growth of Macrobrachium amazonicum (Crustacea: Decapoda: Caridea): variations of a continental population. Iheringia, Sér. Zool. 109: e2019018.

Costa-Souza, A. C., J. R. B. de Souza \& A. O. Almeida. 2019. Growth, sexual maturity and dimorphism in six species of snapping shrimps of the genus Alpheus (Decapoda: Alpheidae). Thalassas. doi.org/ 10.1007/s41208-019-00146-2

Crowl, T. A., W. H. McDowell, A. P. Covich \& S. L. Johnson. 2001. Freshwater shrimp effects on detrital processing and nutrients in a topical headwater stream. Ecology. 82(3): 775-783. 
Covich, A. P., M. A. Palmer \& T. A. Crowl. 1999. The role of benthic invertebrate species in freshwater ecosystems zoobenthic species influence energy flows and nutrient cycling. BioScience. 49(2): 119127.

De Grave, S. \& C. H. J. M. Fransen. 2011. Carideorum catalogus: the recent species of the Dendrobranchiate, Stenopodidean, Procaridean and Caridean shrimps (Crustacea: Decapoda). Zool. Med. 89: 195-589.

De Grave, S., Y. Cai \& A. Anker. 2008. Global diversity of shrimps (Crustacea: Decapoda: Caridea) in freshwater. Hydrobiologia. 595: 287-293.

De Grave, S., N. D. Pentcheff, S. T. Ahyong, T. Y. Chan, K. A. Crandall, P. C. Dworschak, D. L. Felder, R. M. Feldmann, C. H. J. M. Fransen, L. Y. D. Goulding, R. Lemaitre, M. E. Y. Low, J. W. Martin, P. K. L. NG, C. E. Schweitzer, S. H. Tan, D. Tshudy \& R. Wetzer. 2009. A classification of living and fossil genera of decapod crustaceans. Raff. Bull. Zool. 21: 1-109.

Descouterelle, G. 1971. Role of male sexual appendix in the copulation in seminal receptacle female in egg-laying at Atyaephyra demaresti Millet Crustacea-Decapoda-Caridea. Bull. Acad. Lorraine Sci. 10: 10-14.

Dhaouadi-Hassen, S. \& M. Boumaiza. 2005 Croissance relative de l'endopodite sexuel chez trois populations d'Atyaephyra desmaresti (Crustacea, Decapoda, Atyidae) de trois barrages tunisiens (Sidi Salem, Lebna et Sidi Saâd). Zool. Baetica. 16: 3-19.

Flores, A. A. V. \& M. L. Negreiros-Fransozo. 1999. Allometry of the secondary sexual characters of the shore crab Pachygrapsus transversus (Gibbes, 1850) (Brachyura, Grapsidae). Crustaceana. 72: 1051-1066.

Gonçalves, G. R. L., E. A. Bolla Jr., M. L. Negreiros-Fransozo \& A. L. Castilho. 2017. Morphometric and gonad maturity of the spider crab Libinia ferreirae Brito Capello (1871) (Decapoda: Majoidea: Epialtidae) on the south-eastern Brazilian coast. J. Mar. Biol. Ass. UK 97: 289-295.

Grilli, N. M., M. Terossi \& F. L. Mantelatto. 2014. Sexual system of the freshwater shrimps of the genus Potimirim Holthuis (Decapoda: Caridea: Atyidae): is there a pattern in this genus? Mar. Fresh. Res. 65: 759-765.
Hammer, O., D. A. T. Harper \& P. D. Ryan. 2001. Past: Paleontological Statistics Software Package for Education and Data Analysis. Palaeontol. Electron. 4: 1-9.

Hartnoll, R. G. 1974. Variation in growth pattern between some secondary sexual characters in crabs (Decapoda, Brachyura). Crustaceana. 27: 131-136.

Hartnoll, R. G. 1978. The determination of relative growth in crustacea. Crustaceana. 34: 281-293.

Hartnoll, R. G. 1982. Growth. pp. 111-196. In: Abele L. G. \& D. E. Bliss (Eds.). The biology of Crustacea, embryology, morphology and genetics. v. 2, New York, Academic Press.

Herrera, D. R., T. M. Davanso \& R. C. Costa. 2018. Relative growth and morphological sexual maturity of the caridean shrimp Nematopalaemon schmitti (Decapoda: Caridea: Palaemonidae) in an upwelling region in the Western Atlantic. Inv. Rep. \& Dev. 62: 56-62.

Hines, A. H. 1989. Geographic variation in size at maturity in brachyuran crabs. Bull. Mar. Sci. 45: 356-368.

Hirose, G. L. \& M. L. Negreiros-Fransozo. 2007. Growth phases and differential growth between sexes of Uca maracoani Latreille, 1802-1803 (Crustacea, Brachyura, Ocypodidae). Gulf Carib. Res. 19: 4350.

Hirose, G. L., V. Fransozo, J. S. Bolaños, R. M. Shimizu, J. Hernández, R. C. Santos, C. Lira \& M. L. Negreiros-Fransozo. 2017. Allometric growth and morphological sexual maturity of the Atlantic ghost crab Ocypode quadrata (Fabricius, 1887) (Crustacea: Decapoda: Ocypodidae) from three different geographic regions. Bol. Inst. Ocean. Venezuela. 141-153.

Hirose, G. L., V. Fransozo, C. Tropea, L. S. López-Greco \& M. L. Negreiros-Fransozo. 2012. Comparison of body size, relative growth and size at onset sexual maturity of Uca uruguayensis (Crustacea: Decapoda: Ocypodidae) from different latitudes in the south-western Atlantic. J. Mar. Biol. Ass. UK. 93: 781-788.

Hoffmann, P. 2007. Ecologia populacional e reprodutiva de Potimirim glabra (Kingsley, 1954) (Caridea, Atyidae) em riachos da região de Ubatuba-SP. Master Science Dissertation (Zoology), Institute of Biosciences, São Paulo State University (UNESP), Botucatu, SP, Brazil. 96 p. 
Hoffmann, P. \& M. L. Negreiros-Fransozo. 2010. Reproductive cycle and fecundity of Potimirim glabra (Kingsley, 1954) (Caridea, Atyidae) from a littoral stream. Inv. Rep. \& Dev. 54: 133-141.

Huxley, J. S. \& G. Teissier. 1936. Terminologie et notation dans la description de la croissance relative. CR. Soc. Biol. 121: 934-936.

Huxley, J. S. 1950. Relative growth and form transformation. Proc. Zool. Soc. London. 137: 465-469.

Karplus, I. \& A. Sagi. 2010. The biology and management of size variation. pp. 316345. In: New, M. B., W. C. Valenti, J. H. Tidwell, L. R. D'Abramo \& M. N. Kutty. (Eds.). Freshwater Prawns Biology and Farming. Oxford, Wiley-Blackwell.

Karplus, I. \& A. Barki. 2019. Male morphotypes and alternative mating tactics in freshwater prawns of the genus Macrobrachium: a review. Rev. Aquacult. 11: 925940.

Konan, K. M., A. B. Adépo-Gourène, A. Ouattara, W. D. Nyingy \& G. Gourène. 2010. Morphometric variation among male populations of freshwater shrimp Macrobrachium vollenhovenii Herklots, 1851 from Côte d'Ivoire Rivers. Fish. Res. 10: 18.

Legendre, P. \& L. Legendre. 2012. Numerical Ecology. 3rd ed. Elsevier Science. BV, Amsterdam. xvi $+990 \mathrm{p}$.

Lima, G. V., C. M. Silveira \& L. M. Y. Oshiro. 2006. Estrutura populacional dos camarões simpátricos Potimirim glabra e Potimirim potimirim (Crustacea, Decapoda, Atyidae) no Rio Sahy, Rio de Janeiro, Brasil. Iheringia, Sér. Zool. 96: 81-87.

López-Greco, L. S., V. S. Stella \& E. Rodríguez. 1999. Size at onset of the sexual maturity of Chasmagnathus granulata (Decapoda, Brachyura). Nauplius. 5: 65-75.

Lozano-Alvarez, E., P. Briones-Fourzan, A. Gracia \& A. N. Vázquez-Bader. 2007. Relative growth and size at first maturity of the deep water shrimp, Heterocarpus ensifer (Decapoda, Pandalidae) from the Southern Gulf of Mexico. Crustaceana. 80: 555-568.

Mantelatto, F. L. \& L. R. Barbosa. 2005. Population structure and relative growth of freshwater prawn Macrobrachium brasiliense (Decapoda, Palaemonidae) from São Paulo State, Brazil. Acta Lim. Bras. 17: 245-255.
Martínez-Mayén, M., R. Román-Contreras, A. Rocha-Ramírez \& S. ChazaroOlvera. 2000. Relative growth of Atya margaritacea A. Milne-Edwards, 1864 (Decapoda, Atyidae) from the Southern Pacific coast of Mexico. Crustaceana. 73: 525534.

Mortari, R. C., B. G. N. Pralon \& M. L. Negreiros-Fransozo. 2009. Reproductive biology of Palaemon pandaliformis (Stimpson, 1871) (Crustacea, Decapoda, Caridea) from two estuaries in southeastern Brazil. Inv. Rep. \& Dev. 53: 223-232.

Moraes, A. B., D. C. S. Moraes, C. E. R. D. Alencar, W. P. Silva \& F. A. M. Freire. 2017. First record of Potimirim potimirim (Müller, 1881) (Crustacea, Decapoda, Atyidae) from Rio Grande do Norte, Northeastern Brazil. Check List. 13: 2060.

Moraes-Riodades, P. M. C. \& W. C. Valenti. 2002. Crescimento relativo do camarão canela Macrobrachium amazonicum (Heller) (Crustacea, Decapoda, Palaemonidae) em viveiros. Rev. Bras. Zool. 19: 11691176.

Moraes-Riodades, P. M. C. \& W. C. Valenti. 2004. Morphotypes in male Amazon River prawns, Macrobrachium amazonicum. Aquaculture. 236: 297-307.

Mossolin, E. C. \& S. L. S. Bueno. 2003. Relative growth of the second pereiopod in Macrobrachium olfersi (Wiegmann, 1836) (Decapoda: Palaemonidae). Crustaceana. 76: 363-376.

Moulton, T. P., M. L. Souza, R. M. L. Silveira \& F. A. Krsulovic. 2004. Effects of ephemeropterans and shrimps on periphyton and sediments in a coastal stream (Atlantic Forest, Rio de Janeiro, Brazil). J. N. Am. Benthol. Soc. 23: 868-881.

Nakashima, Y. 1995. Can small shrimps achieve copulation in the presence of larger ones? J. Ethol. 5: 145-149.

Nazari, E. M., M. S. Simões-Costa, Y. M. R. Müller, D. Ammar \& M. Dias. 2003. Comparisons of fecundity, egg size and egg volume of the freshwater prawns Macrobrachium potiuna and Macrobrachium olfersi (Decapoda, Palaemonidae). J. Crust. Biol. 23: 862-868.

Negreiros-Fransozo, M. L. \& V. Fransozo. 2003. A study of the mud crab, Panopeus austrobesus Williams, 1983 (Decapoda, Brachyura) from a subtropical mangrove in South America. Crustaceana. 76: 281-294.

Newcombe, C. L. 1948. An application of the allometry equation to the study of the growth in Callinectes sapidus Rathbun. Am. Nat. 82: 315-325. 
Nogueira, C. S., M. S. Oliveira, G. B. Jacobucci \& A. C. Almeida. 2019. Relative growth of freshwater prawn Macrobrachium brasiliense (Decapoda, Palaemonidae) and its implications for reproduction. Iheringia, Sér. Zool. 109: e2019005.

Paschoal, L. R. P., F. J. Guimarães \& E. C. G. Couto. 2013a. Relative growth and sexual maturity of the freshwater shrimp Palaemon pandaliformis (Crustacea, Palaemonidae) in northeastern of Brazil (Canavieiras, Bahia). Iheringia, Sér. Zool. 103: 31-36.

Paschoal, L. R. P., R, N, Souza, F. J. Guimarães \& E. C. G. Couto. 2013b. Phytophilous caridean shrimps (Atyidae and Palaemonidae) in Salsa river (Canavieiras, Bahia, Brazil). Nauplius. 21(1): 123-126.

Pantaleão, J. A. F., G. L. Hirose \& R. C. Costa. 2012. Relative growth, morphological sexual maturity, and size of Macrobrachium amazonicum (Heller 1862) (Crustacea, Decapoda, Palaemonidae) in a population with an entirely freshwater life cycle. Inv. Rep. \& Dev. 56: 180-190.

Pantaleão, J. A. F., G. L. Hirose \& R. C. Costa. 2014. Occurrence of male morphotypes of Macrobrachium amazonicum (Caridea, Palaemonidae) in a population with an entirely freshwater life cycle. Braz. J. Biol. 74: 223-232.

Petriella, A. M. \& E. Boschi. 1997. Crecimiento en crustáceos decápodos: resultados de investigaciones realizadas en Argentina. Invest. Mar. Valparaíso. 25: 135-157.

Pescinelli, R. A., A. O. Almeida \& R. C. Costa. 2018. Population structure, relative growth and morphological sexual maturity of the snapping shrimp Alpheus brasileiro Anker, 2012 (Caridea: Alpheidae) from the south-eastern coast of Brazil. Mar. Biol. Res. 14: 610-620.

Rocha, S. S., S. L. S. Bueno, R. M. Shimizu \& F. L. Mantelatto. 2013. Reproductive biology and population structure of Potimirim brasiliana Villalobos, 1959 (Decapoda, Atyidae) from a littoral fast-flowing stream, Sao Paulo State, Brazil. Crustaceana. 86: 67-83.

Sampedro, M. P., E. González-Gurriarán, J. Freire \& R. Muiño. 1999. Morphometry and sexual maturity in the spider crab Maja squinado (Decapoda: Majidae) in Galicia, Spain. J. Crust. Biol. 19: 578-592.
Souza, M. L. \& T. P. Moulton. 2005. The effects of shrimps on benthic material in a Brazilian island stream. Fresh. Biol. 50: 592-602.

Sokal, R. R. \& F. J. Rohlf. 1995. Biometry: the principles and practice of statistics in biological research. San Francisco, W.H. Freeman. $776 \mathrm{p}$.

Teissier, G. 1935. Croisssance des variants sexuels chez Maja squinado L. Trav. Stat. Biol. Roscoff. 13: 93-130.

Teissier, G. 1960. Relative growth. pp. 537560. In: Waterman, T. H. (Ed.). The Physiology of Crustacea. 1st ed. New York, Academic Press.

Torati, L. S. \& F. L. Mantelatto. 2012. Ontogenetic and evolutionary change of external morphology of the neotropical shrimp Potimirim (Holthuis, 1954) explained by a molecular phylogeny of the genus. J. Crust. Biol. 32: 625-640.

Valenti, W. C., J. T. C. Mello \& V. L. Lobão. 1989. Fecundidade de Macrobrachium acanthurus (Wiegmann, 1836) do Rio Ribeira de Iguape (Crustacea, Decapoda, Palaemonidae). Rev. Bras. Zool. 6: 9-15.

Viau, V. E., L. S. López-Greco, G. BondBuckup \& E. M. Rodriguez. 2006. Size at the onset of sexual maturity in the anomuran crab, Aegla uruguayana (Aeglidae). Acta Zool. 87: 253-264.

Villalobos, F. A. 1959. Contribución al conocimiento de los Atyidae de México. II (Crustacea, Decapoda). Estudio de algunas especies del género Potimirim (=Ortmannia), con descripción de una especie nueva de Brasil. An. Inst. Biol. UNAM. 30: 269330.

Zar, J. H. 1996. Biostatistical analysis. Prentice-Hall, Upper Saddle River, 662 p.

Received on 02.X.2019 Accepted on 27.II.2020 